九州大学学術情報リポジトリ

Kyushu University Institutional Repository

Field Experiment on Long-Term Application of Chemical Fertilizers and Farmyard Manure in Floodplain Soil of Bangladesh

Egashira, Kazuhiko

Faculty of Agriculture, Kyushu Unviersity

Han, Jing-Long

Yantai Unviersity

Satake, Noriko

School of Agriculture, Kyushu University

Nagayama, Tomomi

School of Agriculture, Kyushu University

他

https://doi.org/10.5109/4694

出版情報：九州大学大学院農学研究院紀要. 50 (2)，pp.861-870，2005-10-01. Faculty of Agriculture, Kyushu University

バージョン：

権利関係 : 


\title{
Field Experiment on Long-Term Application of Chemical Fertilizers and Farmyard Manure in Floodplain Soil of Bangladesh
}

\author{
Kazuhiko EGASHIRA*, Jing-Long HAN ${ }^{1}$, Noriko SATAKE ${ }^{2}$, \\ Tomomi NAGAYAMA ${ }^{2}$, M. Joinul Abedin MIAN ${ }^{3}$ \\ and Abu Zofar Md. MOSLEHUDDIN ${ }^{3}$
}

\author{
Laboratory of Soil Science, Division of Soil Science and Plant Production, \\ Department of Plant Resources, Faculty of Agriculture, \\ Kyushu University, Fukuoka 812-8581, Japan \\ (Received June 30, 2005 and accepted July 26, 2005)
}

\begin{abstract}
Field experiment on long-term application of chemical fertilizers and farmyard manure is ongoing in a floodplain soil of Bangladesh since 1978. The treatments are application of N, NP, NK, NPK, NS, NZn, NSZn, NPKSZn, and N+FYM (cowdung as farmyard manure), along with control (no addition), and have been executed in every cropping. Forty-five times of paddy-rice cropping was done before soil sampling in July 2002. Among chemical properties of soil, the organic matter and total $\mathrm{N}$ concentrations, clay mineralogical composition, and the heavy metal concentration were assessed. The organic matter and total $\mathrm{N}$ concentrations of surface soil were increased from those in the initial state, although this was ascribed to continuous cropping of paddy-rice rather than the direct effect of chemical fertilizers and farmyard manure. Clay mineralogical change, such as fixation of $\mathrm{K}$ in the vermiculite interlayer to be transformed into clay mica, was not detected. Accumulation of heavy metals in soil was not noticed.
\end{abstract}

\section{INTRODUCTION}

Bangladesh is situated in the northeastern part of the Indian subcontinent. The total land area is around $147,000 \mathrm{~km}^{2}$ and the greater part of it exists on the Ganges-Brahmaputra delta; climate belongs to the tropical to subtropical monsoon. Agriculture is the mainstay of economy of the country. It contributes to over $30 \%$ of the gross domestic product (GDP) and provides employment for about $60 \%$ of the labor force. Nearly $60 \%$ of the national land is cultivated for different crops throughout the year. Increase in intensification of cropping due to population pressure, however, has caused a gradual decline in soil fertility. An FAO report (FAO-UNDP-UNEP, 1994) estimated $65 \%$ of agricultural land in Bangladesh suffers from soil fertility decline. Moslehuddin et al. (1997) reviewed the fertility status of Bangladesh soils and concluded that the overall status was not satisfactory. Organic matter status has a first priority in conservation of soil fertility in Bangladesh. Approximately $60 \%$ of the soils contain less

\footnotetext{
1 Present address: School of Environment and Material Engineering, Yantai University, Yantai City, Shandong Province, China (Tel: 010-86-5356906203; E-mail: hanjinglong8868@yahoo.co.jp)

2 Department of Bioresource and Bioenvironment, School of Agriculture, Kyushu University, Fukuoka 812-8581, Japan

${ }^{3}$ Department of Soil Science, Bangladesh Agricultural University, Mymensingh-2202, Bangladesh

* Corresponding author (E-mail: kegashi@agr.kyushu-u.ac.jp)
} 
than $2 \%$ organic matter, and $\mathrm{N}$ percentage is very low (Zaman, 1986).

The experiment of long-term application of chemical fertilizers and farmyard manure is ongoing since 1978 at the university farm of Bangladesh Agricultural University of Bangladesh. Soil samples were taken in 2002 after 45 times of cropping of paddy-rice. In the present paper, organic matter status of soil was studied for evaluation of the influence of long-term application of those amendments on the accumulation of organic matter. In addition, the clay mineralogical changes and heavy metal accumulation were examined

\section{FIELD EXPERIMENT}

Description under this heading mostly comes from the MS Thesis of Bilkis (2002), Soil Science Department of Bangladesh Agricultural University (BAU).

\section{Location and soil}

The field experiment was initiated in 1978 at the farm of BAU, Mymensingh, $120 \mathrm{~km}$ north of Dhaka, the capital in Bangladesh. The farm is located on the Old Brahmaputra Floodplain. It comprises Noncalcareous Dark Grey Floodplain soil by the Bangladesh classification system, equivalent to Aeric Haplaquepts by Soil Taxonomy (Saheed, 1984; FAO-UNDP, 1988), and developed from Old Brahmaputra alluvium. The field is on a very gently undulating ridge, above flood level, with imperfect drainage. Selected chemical and physical properties of the initial soil just before starting of the long-term experiment are reproduced in Table 1.

Table 1. Selected chemical and physical properties of the initial soil.

\begin{tabular}{ll}
\hline Property & Value \\
\hline Particle-size distribution (\%) & \\
Sand $(2.0-0.05 \mathrm{~mm})$ & 18.8 \\
Silt $(0.05-0.002 \mathrm{~mm})$ & 63.6 \\
Clay $(<0.002 \mathrm{~mm})$ & 17.6 \\
Texture & Silt loam \\
pH & 6.8 \\
Organic matter (\%) & 1.25 \\
Total N (\%) & 0.06 \\
\hline
\end{tabular}

Measured in 1978 and quoted from Bilkis (2002).

\section{Treatments}

Ten treatments were set up in the field experiment. Those were control (no addition), and application with $\mathrm{N}(\mathrm{N}$, expressed similarly thereafter), $\mathrm{N}$ and $\mathrm{P}(\mathrm{NP}), \mathrm{N}$ and $\mathrm{K}$ (NK), N and P and K (NPK), N and S (NS), N and Zn (NZn), N and S and Zn (NSZn), N and $P$ and $K$ and $S$ and $Z n$ (NPKSZn), and $N$ and farmyard manure (N+FYM). The application rates of $\mathrm{N}, \mathrm{P}, \mathrm{K}, \mathrm{S}$, and $\mathrm{Zn}$ per crop were $70,20,19,30$, and $8 \mathrm{~kg} \mathrm{ha}^{-1}$, respectively. Urea, triple superphosphate, muriate of potash, gypsum, and zinc sulfate were used as sources of N, P, K, S, and Zn, respectively. Cowdung was used as farmyard manure at a rate of $5.0 \mathrm{Mg} \mathrm{ha}^{-1}$. Chemical fertilizers and cowdung were applied in every cropping and 
incorporated to soil during final land preparation, except for $\mathrm{N}$ in which three equal splits were applied as basal-dressing and two times of top-dressing. The above application rates were not different between Aus and T. Aman and between high-yielding and local varieties.

\section{Cropping}

After initiation of the field experiment, rice (Aus and T. Aman) was normally grown 2 to 3 times in a year following rainfed- and irrigated-rice-based cropping patterns. Usually, Aus is planted in mid-March to mid-April and is harvested in June, and the growing season of T. Aman (Transplanted Aman) ranges from mid-July to mid-December (Zaman, 1986). Irrigation water from a deep tubewell was given to the plots. A sum of 46 rice crops has been harvested up to the end of 2002, of which 29 were high-yielding varieties and 17 were local varieties. Rice grain yields of the selected treatments in 1982 , 1995 and 2002 are reproduced in Table 2, quoted from Bilkis (2002).

Table 2. Rice grain yields $\left(\mathrm{Mg} \mathrm{ha}^{-1}\right)$ of the selected treatments.

\begin{tabular}{lcccccc}
\hline \multirow{2}{*}{ Treatment } & 1982 & \multicolumn{3}{c}{1995} & \multicolumn{2}{c}{2002} \\
\cline { 2 - 7 } & Aus & T. Aman & Aus & T. Aman & Aus & T. Aman \\
\hline Control & 1.4 & 2.1 & 1.5 & 2.0 & 3.0 & 3.3 \\
N & 2.1 & 3.3 & 2.1 & 2.6 & 4.5 & 3.6 \\
NP & 2.8 & 3.3 & 2.3 & 3.0 & 4.5 & 5.0 \\
NPK & 2.1 & 3.4 & 2.6 & 3.2 & 4.7 & 6.1 \\
NS & 2.2 & 4.0 & 2.6 & 3.6 & 5.0 & 6.3 \\
NPKSZn & 4.0 & 5.4 & 3.2 & 4.6 & 4.3 & 6.8 \\
N+FYM & 3.5 & 4.9 & 3.5 & 3.8 & 4.2 & 4.5 \\
\hline
\end{tabular}

Quoted from Bilkis (2002). Refer to the text for the treatments.

\section{MATERIALS AND METHODS}

\section{Soil sample}

Soil samples were taken from $0-10 \mathrm{~cm}$ (surface) and 10-20 cm (subsurface) depths at 5 spots in each of three replicated plots of the individual treatment in July 2002 . They were air-dried, gently ground, and passed through a 2-mm sieve to prepare the composite soil sample of the individual treatment. Therefore, statistical analysis to reveal significant differences between the treatments was not carried out.

\section{Chemical and mineralogical analyses}

Total $\mathrm{C}$ and $\mathrm{N}$ concentrations of both surface and subsurface soils were determined by $\mathrm{N} \cdot \mathrm{C}$ analyzer (Sumigraph $\mathrm{NC}-80$ Auto, Sumitomo Chemical Ltd.) (Editorial Committee for Methods of Soil Environmental Analysis, 1997). The determination was made in duplicate to take average. The total $\mathrm{C}$ was regarded as the organic form because of the noncalcareous nature of the soil and its concentration was multiplied by a factor of 
1.724 to convert it to the organic matter concentration. Heavy metals were extracted from surface soil in duplicate with concentrated nitric and hydrochloric acids (Keller and Vedy, 1994) followed by the determination by an atomic absorption spectrophotometer. Clay mineralogical composition was semi-quantitatively estimated based on the relative peak intensities of XRD (X-ray diffraction) patterns, after separation of the $<2 \mu$ m clay fraction from surface soil by the sedimentation method (Wada, 1966).

\section{RESULTS}

\section{Organic matter status}

Table 3 shows the organic matter and total $\mathrm{N}$ concentrations of surface soils. They were in ranges between 21.0 and $26.7 \mathrm{~g} \mathrm{~kg}^{-1}$ and between 1.22 and $1.53 \mathrm{~g} \mathrm{~kg}^{-1}$. The organic matter concentration exceeded the critical value of $20.0 \mathrm{~g} \mathrm{~kg}^{-1}$ (Zaman, 1986) and the total $\mathrm{N}$ concentration was considerably over $1.0 \mathrm{~g} \mathrm{~kg}^{-1}$ in all treatments including the control. In addition, the organic matter and total $\mathrm{N}$ concentrations measured in the present study were 1.7 to 2.1 and 2.0 to 2.6 times, respectively, higher than those of the initial soil (Table 1). During 24 years the organic matter and total $\mathrm{N}$ concentrations of surface soil increased to around or more than double from the initial state in all the plots amended with different chemical fertilizers and farmyard manure. It clearly indicates the improvement of organic matter status of surface soil after 24 years of the experiment. Among the treatments, the N+FYM treatment showed the highest concentrations of organic matter and total N, followed by the NPK treatment. However, the organic matter and total N concentrations of the other treatments were nearly equal or even below the concentrations for the control without addition of chemical fertilizers and farmyard manure.

The organic matter and total $\mathrm{N}$ concentrations of subsurface soils were considerably lower than those of surface soils and ranged from 10.5 to $17.8 \mathrm{~g} \mathrm{~kg}^{-1}$ and from 0.62 to $1.07 \mathrm{~g} \mathrm{~kg}^{-1}$, respectively, as shown in Table 4 . The organic matter and total $\mathrm{N}$ concentrations of subsurface soil were outstandingly higher in the NPK and NS treatments. In the other treatments, however, the organic matter and total $\mathrm{N}$ concentrations were not much different from the values of the control and remained around the level of the initial

Table 3. Organic matter and total $\mathrm{N}$ concentrations $\left(\mathrm{g} \mathrm{kg}^{-1}\right.$ ) of surface soils.

\begin{tabular}{lcc}
\hline Treatment & Organic matter & Total N \\
\hline Control & 23.9 & 1.41 \\
N & 23.4 & 1.39 \\
NP & 24.5 & 1.42 \\
NK & 23.0 & 1.35 \\
NPK & 25.6 & 1.50 \\
NS & 21.0 & 1.22 \\
NZn & 23.7 & 1.39 \\
NSZn & 21.5 & 1.28 \\
NPKSZn & 24.4 & 1.42 \\
N+FYM & 26.7 & 1.53 \\
\hline
\end{tabular}

Refer to the text for the treatments. 
Table 4. Organic matter and total $\mathrm{N}$ concentrations $\left(\mathrm{g} \mathrm{kg}^{-1}\right)$ of subsurface soils.

\begin{tabular}{lcc}
\hline Treatment & Organic matter & Total N \\
\hline Control & 11.5 & 0.64 \\
N & 10.5 & 0.62 \\
NP & 14.1 & 0.83 \\
NK & 11.3 & 0.65 \\
NPK & 17.8 & 1.07 \\
NS & 17.3 & 1.04 \\
NZn & 10.7 & 0.62 \\
NSZn & 13.4 & 0.78 \\
NPKSZn & 12.8 & 0.75 \\
N+FYM & 13.9 & 0.78 \\
\hline
\end{tabular}

Refer to the text for the treatments.

soil (Table 1). This was considered as the result that the improvement of organic matter status by chemical fertilizers and farmyard manure was still limited to surface soil and did not reach to subsurface soil in the present field experiment even after 24 years of their continuous application.

\section{Clay mineralogical composition}

Figures 1 and 2 show XRD patterns of the clay fraction separated from surface soils of the NPK treatment as a representative of the chemical and organic treatments and of the control, respectively. From the XRD patterns, vermiculite, clay mica and kaolinite

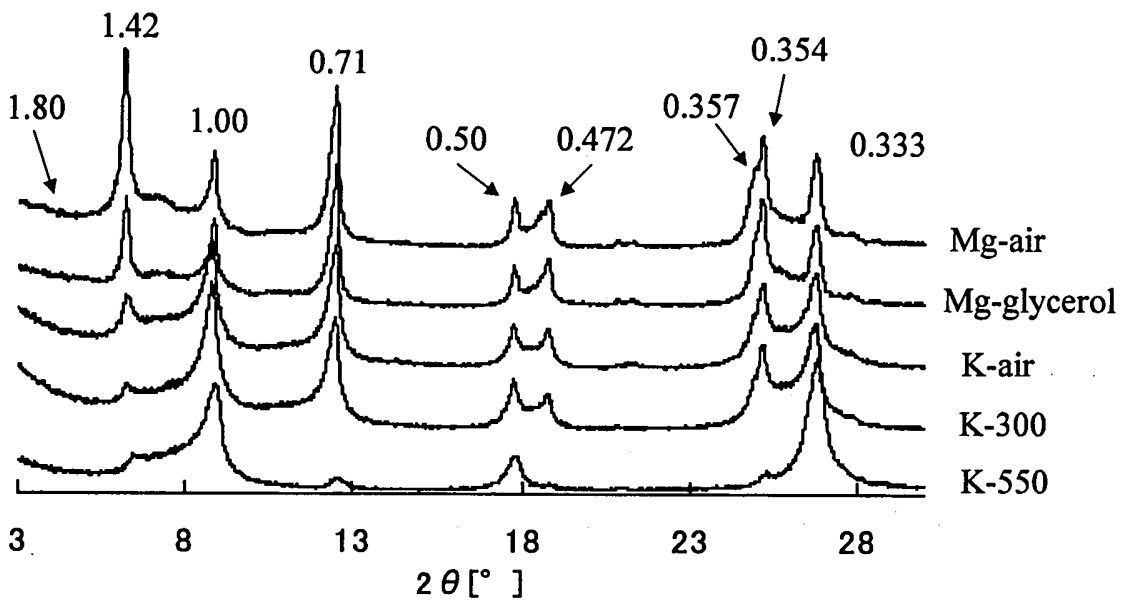

Fig. 1. XRD patterns of the $<2 \mu \mathrm{m}$ clay fraction separated from surface soil of the NPK treatment. Spacing is in nm. Treatments: $\mathrm{Mg}$-air, $\mathrm{Mg}$-saturation and air-drying; $\mathrm{Mg}$-glycerol, $\mathrm{Mg}$-saturation and glycerol-solvation; K-air, K-saturation and air-drying; K-300, $\mathrm{K}$-saturation and heating at $300^{\circ} \mathrm{C} ; \mathrm{K}-550, \mathrm{~K}$-saturation and heating at $550^{\circ} \mathrm{C}$. 


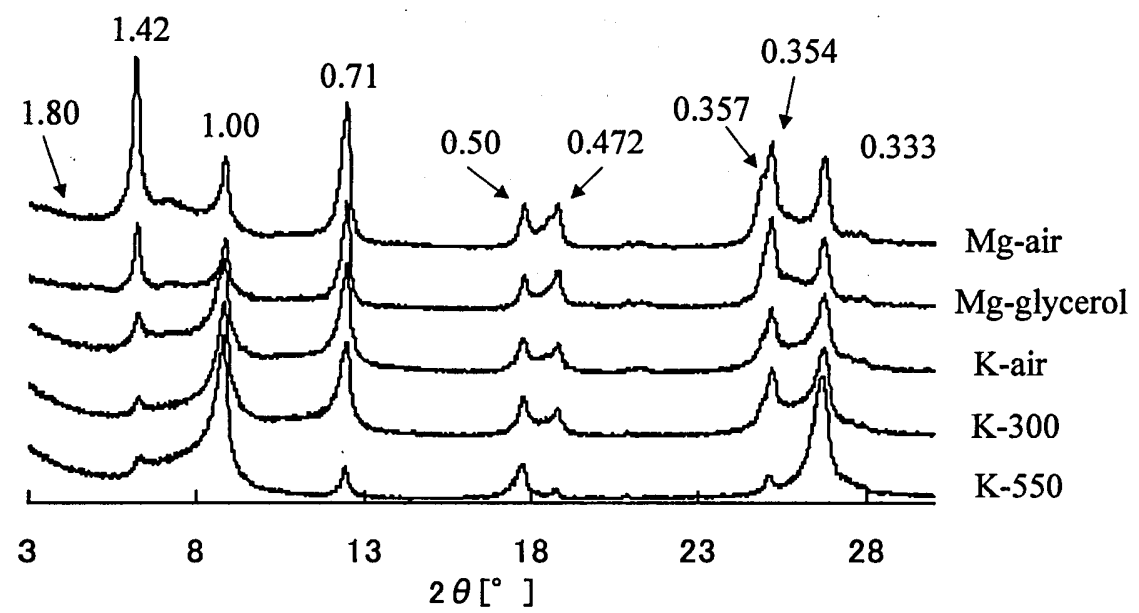

Fig. 2. XRD patterns of the $<2 \mu \mathrm{m}$ clay fraction separated from surface soil of the control. Spacing is in nm. Refer to Fig. 1 for the treatments.

Table 5. Approximate mineralogical composition of layer silicates in the clay fraction.

\begin{tabular}{lcccc}
\hline \multirow{2}{*}{ Treatment } & \multicolumn{4}{c}{ Minerals $^{1)}(\%)$} \\
\cline { 2 - 5 } & Mc & Vt+Vt-Ch & Ch & Kt \\
\hline Control & 17 & 60 & 5 & 18 \\
N & 17 & 59 & 9 & 16 \\
NK & 16 & 62 & 8 & 15 \\
NPK & 16 & 61 & 5 & 18 \\
NPKSZn & 18 & 59 & 9 & 14 \\
N+FYM & 18 & 59 & 5 & 18 \\
\hline
\end{tabular}

1) Abbreviations: Mc, clay mica; Vt, vermiculite; Vt-Ch, vermiculite-chlorite intergrade; $\mathrm{Ch}$, chlorite; Kt, kaolinite. Refer to the text for the treatments.

were identified as main clay minerals with minor amounts of vermiculite-chlorite intergrade and chlorite. The approximate mineralogical composition of layer silicates in the clay fraction was estimated based on the relative peak intensities for the respective minerals and is shown in Table 5. Essentially no difference was found in the mineralogical composition of the clay fraction among the selected six treatments.

\section{Heavy metal concentration}

Table 6 shows the concentrations of $\mathrm{Cd}, \mathrm{Pb}, \mathrm{Zn}$ and $\mathrm{Cu}$ of surface soils extracted with concentrated nitric and hydrochloric acids. They were in narrow ranges of 0.25 to 0.52 , 10.7 to $14.8,92.7$ to 97.7 , and 64.6 to $66.2 \mathrm{mg} \mathrm{kg}^{-1}$ for $\mathrm{Cd}, \mathrm{Pb}, \mathrm{Zn}$, and $\mathrm{Cu}$, respectively. Essentially no difference was noted in the total concentrations of $\mathrm{Cd}, \mathrm{Pb}, \mathrm{Zn}$ and $\mathrm{Cu}$ 
Table 6. Concentrations ( $\mathrm{mg} \mathrm{kg}^{-1}$ ) of $\mathrm{Cd}, \mathrm{Pb}, \mathrm{Zn}$ and $\mathrm{Cu}$ of surface soils.

\begin{tabular}{lcccc}
\hline Treatment & $\mathrm{Cd}$ & $\mathrm{Pb}$ & $\mathrm{Zn}$ & $\mathrm{Cu}$ \\
\hline Control & 0.40 & 14.1 & 93.0 & 65.3 \\
N & 0.47 & 14.1 & 95.5 & 66.2 \\
$\mathrm{NP}$ & 0.37 & 14.8 & 95.1 & 65.9 \\
$\mathrm{NK}$ & 0.40 & 12.8 & 92.7 & 65.3 \\
NPK & 0.33 & 11.4 & 93.6 & 64.6 \\
NS & 0.25 & 12.1 & 94.6 & 65.8 \\
NZn & 0.47 & 11.4 & 95.2 & 66.2 \\
NSZn & 0.42 & 13.5 & 97.0 & 65.4 \\
NPKSZn & 0.52 & 10.7 & 97.7 & 66.1 \\
N + FYM & 0.42 & 11.1 & 94.8 & 66.1 \\
\hline
\end{tabular}

Refer to the text for the treatments.

among the treatments, and the concentrations of the four heavy metals of the treated plots were not different from those of the control.

\section{DISCUSSION}

\section{Improvement of organic matter status}

Organic matter status of the floodplain soil on the Old Brahmaputra Floodplain in Bangladesh was improved by continuous application of chemical fertilizers and farmyard manure of 24 years (1978 to 2002). The improvement of organic matter status was limited to the surface soil ( 0 to $10 \mathrm{~cm}$ deep) in most treatments. Among the chemical fertilizers tested, the combination of NPK was found to be most effective on the accumulation of organic matter. Application of cowdung at the rate of $5.0 \mathrm{Mg} \mathrm{ha}^{-1}$ per crop contributed to the additional accumulation of organic matter. However, the improvement of organic matter status was also recognized to the control (no addition of chemical fertilizers and farmyard manure) which showed the similar level of the concentrations of organic matter and total $\mathrm{N}$ to the $\mathrm{N}$ treatment with or without other chemical fertilizers. It means that the improvement of organic matter status of surface soil recognized in the present field experiment is not due to the direct effect of continuous application of chemical fertilizers and farmyard manure but has been performed probably through remaining and accumulation of crop residues.

Table 2 reproduced rice grain yields of the selected treatments in 1982, 1995, and 2002, quoted from Bilkis (2002). The grain yield was mostly higher for T. Aman than for Aus in the same year and tended to increase with year even in the control. The grain yield of the NPKSZn treatment was higher than that of the NPK treatment, except for Aus in 2002, suggesting the additional contribution of S and/or Zn to increase in the grain yield. The relative contribution of cowdung to increase in the grain yield was gradually reduced with year. The grain yield was not necessarily related to the organic matter status of soil, and the grain yield of the control was always lowest among the treatments in every year and season of cropping. 
Therefore, it was considered that organic matter status was improved by continuous cropping of paddy-rice in the floodplain soil of the Old Brahamputra Floodplain. Under the subtropical monsoon climate of Mymensingh chemical fertilizers and farmyard manure show the fertilizer effect to a crop and mainly contribute to the increase in the grain yield of paddy-rice of that cropping season. Without application of chemical fertilizers and farmyard manure the grain yield of paddy-rice is kept in a low level, but continuous cropping is more effective to improve organic matter status or soil fertility of the floodplain soil used for paddy-rice cropping.

Increase in the total $\mathrm{N}$ concentration of surface soil by remaining and accumulation of crop residues was estimated to the control plot with several assumptions. The average rice grain yield was calculated to be $2.2 \mathrm{Mg} \mathrm{ha}^{-1}$ based on the data of Table 2 . Corresponding to this value, the total mass of stem, leaf and root which were added to field was regarded as $2.2 \mathrm{Mg} \mathrm{ha}^{-1}$ with assumption of the equal mass of the grain and the total of stem, leave and root. The average $\mathrm{N}$ concentration of stem, leaf and root was assumed to be $5.0 \mathrm{~g} \mathrm{~kg}^{-1}$ for the Indica-type rice. Calculation of the following equation gives the value of $495 \mathrm{~kg} \mathrm{ha}^{-1}$ as the amount of $\mathrm{N}$ added to soil through 45 times of cropping: $2200 \times 0.005 \times 45$. If we assume $1.2 \mathrm{Mg} \mathrm{m}^{-3}$ as bulk density of soil with a soil depth of $10 \mathrm{~cm}$, it gives soil mass of $1.2 \times 10^{6} \mathrm{~kg} \mathrm{ha}^{-1}$. So, the increase in the $\mathrm{N}$ concentration of soil is calculated to be $0.41 \mathrm{~g} \mathrm{~kg}^{-1}$. Addition of this value to the total $\mathrm{N}$ concentration of the initial soil of $0.6 \mathrm{~g} \mathrm{~kg}^{-1}$ (Table 1) gives $1.01 \mathrm{~g} \mathrm{~kg}^{-1}$ as the total $\mathrm{N}$ concentration of surface soil of the control plot. The determined value of surface soil of the control plot was $1.41 \mathrm{~g} \mathrm{~kg}^{-1}$ (Table 3) and exceeded considerably the calculated one. Underestimation of the total mass and the average $\mathrm{N}$ concentration of stem, leaf and root and additional supply of $\mathrm{N}$ by biological $\mathrm{N}$ fixation and through rainfall and irrigation water are considered as reasons of disagreement between the two values.

If we assume the value of $10.0 \mathrm{~g} \mathrm{~kg}^{-1}$ as the average $\mathrm{N}$ concentration of stem, leaf and root, which is reported to the Japonica-type rice, it gives the comparable value of $1.43 \mathrm{~g}$ $\mathrm{kg}^{-1}$ as the total $\mathrm{N}$ concentration of surface soil of the control plot. In the above calculation, however, all $\mathrm{N}$ from crop residues was assumed to accumulate in soil. Usually, some parts of soil $\mathrm{N}$ are adsorbed by crops after mineralization. Why the total $\mathrm{N}$ concentration was increased, meaning the improvement of organic matter status; in the control plot after continuous cropping of paddy-rice and hence what is the source of $\mathrm{N}$ are a big puzzle.

\section{Clay mineralogical change}

Main target of the clay mineralogical change was transformation of vermiculite into clay mica. About $60 \%$ of layer silicate minerals in the clay fraction was occupied by vermiculite and vermiculite-chlorite intergrade (mainly vermiculite) (Table 5 and Fig. 2), and decrease in the vermiculite percentage along with the corresponding increase in the clay mica percentage was expected by continuous addition of $\mathrm{K}$ to soil through application of K-containing fertilizer or farmyard manure. However, such mineralogical change was not noticed from the clay mineral analysis. In this context, total amounts of $\mathrm{K}$ added to soil by $\mathrm{K}$-containing fertilizer and farmyard manure were calculated.

In each cropping $19 \mathrm{~kg} \mathrm{ha}^{-1}$ of $\mathrm{K}$ was added as muriate of potash, and total amount became to $855 \mathrm{~kg} \mathrm{ha}^{-1}$ by multiplying it by 45 times of cropping. If we assume $1.2 \mathrm{Mg} \mathrm{m}^{-3}$ 
as bulk density of soil with a soil depth of $10 \mathrm{~cm}$, the value of $855 \mathrm{~kg} \mathrm{ha}^{-1}$ is equivalent to $0.713 \mathrm{~g} \mathrm{~kg}^{-1}$ or $1.82 \mathrm{cmol}_{\mathrm{c}} \mathrm{kg}^{-1}$ of $\mathrm{K}$. The CEC (cation exchange capacity) of the soil was measured as $7.3 \mathrm{cmol}_{\mathrm{c}} \mathrm{kg}^{-1}$, and the value of $1.82 \mathrm{cmol}_{\mathrm{c}} \mathrm{kg}^{-1}$ of $\mathrm{K}$ was about one-fourth of the CEC. Total amount of $\mathrm{K}$ added by $\mathrm{K}$-containing fertilizer may not be enough for transformation of vermiculite into clay mica in the field.

Similarly, total amount of $\mathrm{K}$ added through application of farmyard manure was calculated, under assumption that all $\mathrm{K}$ included in cowdung was released to soil by mineralization of it. The data concerning cowdung used in the farm of BAU were quoted from Bhuiyan (2004) as follows: the dry matter mass of $5.0 \mathrm{Mg}$ of wet cowdung was $1.73 \mathrm{Mg}$ and the $\mathrm{K}$ concentration of dry cowdung was $1.02 \%$. The amount of $\mathrm{K}$ of $5.0 \mathrm{Mg} \mathrm{ha}^{-1}$ wet cowdung is equivalent to $17.6 \mathrm{~kg}$. Multiplication of $17.6 \mathrm{~kg}$ by 45 times gives $792 \mathrm{~kg}$. It amounted to $0.660 \mathrm{~g} \mathrm{~kg}^{-1}$ or $1.69 \mathrm{cmol}_{\mathrm{c}} \mathrm{kg}^{-1}$ of $\mathrm{K}$ and was in the similar level of $\mathrm{K}$ added by $\mathrm{K}$-containing fertilizer. Potassium is additionally supplied through irrigation water, but fixation of $\mathrm{K}$ in the interlayer of vermiculite was not revealed with mineralogical change. Potassium added to soil through application of $\mathrm{K}$-containing fertilizer or farmyard manure during 24 years was not enough to cause fixation of $\mathrm{K}$ in the vermiculite interlayer. Much more $\mathrm{K}$ is needed for even partial fixation of $\mathrm{K}$ in the vermiculite interlayer under the field condition where reaction of added $\mathrm{K}$ with vermiculite does not proceed so effectively as in the laboratory.

\section{Heavy metal accumulation}

Possible accumulation of heavy metals was expected by continuous application of chemical fertilizers and farmyard manure, because they are usually contaminated with different heavy metals. However, accumulation of heavy metals caused by those materials did not attain to a noticeable level after 24 years from initiation of the experiment. Moslehuddin et al. (1999) reported the concentrations of heavy metals for the selected Bangladesh paddy soils. According to them, the total concentrations of $\mathrm{Pb}, \mathrm{Zn}$ and $\mathrm{Cu}$ for the Lokdeo series of the Old Brahmaptura Floodplain were $39,69.8$ and $23.8 \mathrm{mg} \mathrm{kg}^{-1}$, respectively. Comparison of those values with the present data indicated that surface soil of the present study (university farm, BAU) contained higher $\mathrm{Zn}$ and $\mathrm{Cu}$ by 25 and $42 \mathrm{mg}$ $\mathrm{kg}^{-1}$, respectively, while lower $\mathrm{Pb}$ by $26 \mathrm{mg} \mathrm{kg}^{-1}$ than did the Lokdeo series. Although such differences in the $\mathrm{Pb}, \mathrm{Zn}$ and $\mathrm{Cu}$ concentrations are probably attributed to the site difference even if both soils are distributed on the same physiographic unit and are derived from Old Brahmaputra alluvium, another possibility is supply of $\mathrm{Zn}$ and $\mathrm{Cu}$ to the soil of the BAU farm through agricultural practices such as irrigation.

\section{CONCLUSIONS}

Influences of the long-term application of chemical fertilizers and farmyard manure on chemical properties of paddy-soil were examined at the farm of Bangladesh Agricultural University, Bangladesh. The organic matter status was improved in the surface soil. But, this was ascribed to the continuous cropping of paddy rice, leading to remaining and accumulation of crop residues, and the fertilizer effect of chemical fertilizers and farmyard manure mainly contributed to increase in the grain yield of paddy-rice of that cropping season. Mineralogical change of the clay fraction was not 
detected and accumulation of heavy metals in soil was not noticed.

\section{REFERENCES}

Bilkis, S. 2002 Fractionation of Phosphorus and Potassium in Soil Amended with Organic and Inorganic Fertilizers. MS Thesis (Mimeographed). Bangladesh Agricultural University, Mymensingh (Bangladesh)

Bhuiyan, Md. A. H. 2004 Evaluation of Introducing Mungbean into Cereal Based Cropping Pattern for Sustainable Soil Fertility and Productivity. Ph.D. Thesis (Mimeographed). Bangladesh Agricultural University, Mymensingh (Bangladesh)

Editorial Committee for Methods of Soil Environmental Analysis 1997 Methods of Soil Environmental Analysis. Hakuyusha, Tokyo (in Japanese)

FAO-UNDP 1988 Land Resources Appraisal of Bangladesh for Agricultural Development, Report No.2, Agroecological Regions of Bangladesh, BGD/81/035. Technical Report No. 2, FAO, Rome (Italy)

FAO-UNDP-UNEP 1994 Land Degradation in South Asia: Its Severity, Causes and Effects upon the People. World Soil Resources Reports 78, FAO, Rome (Italy)

Keller, C. and J. C. Vedy 1994 Distribution of copper and cadmium fractions in two forest soils. J. Environ. Qual., 23: 987-999

Moslehuddin, A. Z. M., S. Laizoo and K. Egashira 1997 Fertility status of Bangladesh soils - A review -. J. Fac. Agric. Kyushu Univ., 41: 257-267

Moslehuddin, A. Z. M., S. Laizoo and K. Egashira 1999 Trace elements in Bangladesh paddy soils. Commun. Soil Sci. Plant Anal, 30: 1975-1996

Saheed, S. M. 1984 Soils of Bangladesh. In "Proceedings of the International Symposium on Soil Test Crop Response Correlation Studies", Bangladesh Agricultural Research Council and Soil Science Society of Bangladesh, Dhaka (Bangladesh), pp. 107-129

Wada, K. 1966 Identification and determination of clay minerals. Jpn. J. Soil Sci. Plant Nutr., 38: 9-17 (in Japanese)

Zaman, S. M. H. 1986 Current Status and Prospects for Rainfed Foodgrain Production in Bangladesh. Bangladesh Rice Research Institute, Gazipur (Bangladesh) 